\title{
Disputa licitatória entre bancos para administração de depósitos judiciais
}

\author{
Conselho Nacional de Justiça (CNJ)
}

\author{
Autos: $\quad$ PEDIDO DE PROVIDÊNCIAS - 0004420-14.2019.2.00.0000 \\ Requerente: TRIBUNAL DE JUSTIÇA DO ESTADO DE SÃO PAULO - \\ TJSP \\ Requerido: CONSELHO NACIONAL DE JUSTIÇA - CNJ
}

\section{Ementa:}

PEDIDO DE PROVIDÊNCIAS RECEBIDO COMO CONSULTA. DEPÓSITOS JUDICIAIS NÃO TRIBUTÁRIOS. EFETIVAÇÃO PERANTE BANCOS PRIVADOS. POSSIBILIDADE. ADEQUAÇÃO AO CASO CONCRETO. INTERPRETAÇÃO DE DISPOSITIVOS LEGAIS E REGULAMENTARES APLICÁVEIS. CONSULTA CONHECIDA.

1. O Tribunal apresenta questionamento que toca à administração dos recursos financeiros apreendidos pelo Poder Judiciário e alocados em instituição bancária responsável pela guarda e atualização dos respectivos valores. Mais especificamente, indaga sobre a possibilidade de deflagrar disputa licitatória para contratação de serviços de administração dos depósitos judiciais com participação de bancos públicos e privados. 
2. Conforme consignado, ao empregar o advérbio preferencialmente (art. 840 do CPC), o legislador atribuiu margem de discricionariedade ao agente público, facultando-lhe o exercício de escolhas motivadas, devidamente fundamentadas na realidade do caso concreto. Respeitada a evolução histórico-sistemática da norma, tem o condão de assegurar o reconhecimento da necessária autonomia do Tribunal (e do respectivo juízo) em poder avaliar a proposta mais adequada para a administração dos depósitos judiciais, afastando aquelas economicamente desvantajosas para a rentabilidade das contas.

3. Consulta conhecida e respondida positivamente.

\section{Relatório}

Trata-se de Pedido de Providências, com pedido de liminar, proposto pelo TRIBUNAL DE JUSTIÇA DO ESTADO DE SÃO PAULO - TJSP, por meio do qual requer autorização do CONSELHO NACIONAL DE JUSTIÇA $\mathrm{CNJ}$, para deflagrar disputa licitatória entre bancos públicos e privados para contratação de serviços de administração de depósitos judiciais.

Afirma, inicialmente, que em razão do iminente encerramento do prazo de vigência do Contrato no $147 / 2014$, celebrado entre o TJSP e o Banco do Brasil S/A, a ocorrer em 15.08.2019, se deparou com alguns questionamentos que demandam esclarecimento pelo Conselho Nacional de Justiça, notadamente para orientar o procedimento de administração dos depósitos judiciais. Sustenta que diversas mutações legislativas ocorreram nos últimos anos, alterando significativamente as circunstâncias consideradas pelo $\mathrm{CNJ}$ em seus precedentes anteriores sobre a matéria, a demandar nova avaliação pelo Plenário deste Conselho.

O Tribunal aduz que as normas aplicáveis aos depósitos judiciais se encontram positivadas no Código Civil, artigos 334 a 345, 506 e 635, 647 e seguintes, que disciplinam o contrato de depósito; bem como no Código de Processo Civil de 2015, cujos artigos 539, §1ํㅜ, 840 e 1.058 indicam a necessidade de os valores serem depositados preferencialmente em bancos oficiais. Relativamente ao regime jurídico para administração e gerenciamento, informa que o $\mathrm{CNJ}$, em momento histórico diverso, decidiu que os depósitos devem ser realizados preferencialmente em instituições financeiras públicas, admitindo-se em estabelecimentos privados apenas na hipótese de inexistirem bancos públicos na localidade da sede do órgão do Poder Judiciário. 
Não obstante, o TJSP considera que os precedentes deste Conselho não apenas fundem o conceito de "depósito judicial" ao de "disponibilidade de caixa", em desconformidade com o Código Civil; como também restringem o conceito de banco oficial a banco público, adotando dicotomia não mais existente no nosso regime constitucional. O Tribunal relata que os valores depositados judicialmente são de propriedade das partes e, por corolário, não podem ser classificados como disponibilidade financeira do Estado. Assim, se os depósitos não se classificam como disponibilidade financeira do Estado, não se aplicando o disposto artigo 164, §3º, da Constituição Federal, considera necessária a revisão dos precedentes do $\mathrm{CNJ}$, os quais, com fulcro no mencionado dispositivo, impõem aos Tribunais a obrigatoriedade de conferir "exclusividade" aos bancos públicos para a administração dos valores que são depositados em juízo.

Sustenta que a Emenda Constitucional no 40/2003 trouxe relevante novidade sobre a matéria, esclarecendo que "Oficial" é qualquer instituição bancária integrante do Sistema Financeiro Nacional, independentemente do seu controle ser público ou privado. Relata que ao revogar os incisos do art. 192 da Constituição, o constituinte extirpou a dicotomia anteriormente existente entre bancos públicos e privados. Entende que o termo "banco oficial" empregado no CPC (art. 539) deve ser contextualizado à nova técnica legislativa. O Tribunal assevera que a interpretação histórico-sistemática da atual redação conferida aos artigos 164, §3º , 170, IV, 173, §º , e 192 da Constituição evidencia que não mais subsiste a diferenciação entre instituições públicas e privadas, sendo ambas pertencentes ao gênero "instituições financeiras oficiais".

Na análise da legislação adjetiva, o TJSP entende que a única interpretação constitucionalmente legítima do termo "preferencialmente", constante do caput do artigo 840 do CPC (art. 666 do Código anterior), se revela a partir de sua harmonização com os princípios da licitação e da eficiência, aplicáveis à Administração Pública, e os da livre-iniciativa e ampla concorrência, orientadores da Ordem Econômica Constitucional.

Sustenta que o cenário econômico existente no momento da promulgação da Constituição de 1988, sobretudo em relação ao sistema financeiro, foi profundamente alterado ao longo dos anos. Relata que desde a década de 90 dezenas de bancos públicos foram privatizados por meio do Plano Nacional de Desestatização (Lei no 9.491/97). Considera que a atual política do Banco Central do Brasil tem proporcionado a construção de instituições sólidas e saudáveis, independentemente da natureza pública ou privada. 
Nessa perspectiva, aduz que o contexto econômico em que a Constituição de 1988 foi regida foi profundamente alterado: de uma economia instável nas décadas de 80 e 90, que exigia significativa intervenção estatal para fomento do mercado financeiro, marcada pela presença de uma gama de instituições financeiras públicas capazes de realizar investimentos de grande porte, iniciamos o século com forte estabilidade monetária, controle inflacionário e instituições de crédito deficitárias, a indicar a dispensabilidade de tais agentes do Sistema Financeiro Nacional.

O Tribunal reafirma a tese de que a Emenda Constitucional no 40/2003 extirpou a dicotomia anteriormente existente entre bancos públicos e privados; e que os valores depositados judicialmente não podem ser classificados como "disponibilidade financeira do Estado", não se aplicando, por esta razão, o disposto no artigo 164, $\S^{3}$, da Constituição Federal, constantemente invocado nas decisões desse Conselho. Considera, ainda, que a imposição de contratação de determinada instituição financeira fere a autonomia administrativa e financeira constitucionalmente confiada aos tribunais. O TJSP sustenta que, "sob o prisma do neoprocessualismo", a correta interpretação do artigo 840 do Novo Código de Processo Civil surge do cotejo com os princípios constitucionais da licitação, livre-iniciativa, livre concorrência, isonomia, moralidade e eficiência, os quais, no seu entender, impedem que bancos privados sejam excluídos da atividade de administração dos depósitos judiciais.

Aduz que o princípio constitucional da livre-iniciativa, constante do art. $1^{\circ}$, IV, e art. 170 da Constituição, garante que todos os agentes sejam livres para se dedicar a atividades econômicas e, assim, atuar no mercado, devendo ser assegurada igualdade de condições para que todas as instituições, públicas e privadas, possam concorrer livremente e garantida a isonomia. O Tribunal considera que a excepcional exploração direta da atividade econômica pelo Estado "somente se justifica quando necessária aos imperativos da segurança nacional ou ao relevante interesse coletivo".

Neste sentido, cita entendimento doutrinário de juristas como Cândido Rangel Dinamarco, Celso Antonio Bandeira de Mello, Luís Roberto Barroso e outros, os quais lecionam sobre a imprescindibilidade da livre concorrência de mercado e a impossibilidade de monopólio econômico em favor de bancos estatais, sob pena de flagrante violação dos princípios constitucionais da livre iniciativa e da livre concorrência.

$\mathrm{Na}$ análise das lições doutrinárias e jurisprudenciais, o TJ sustenta que o STF, no julgamento da ADI n⿳0 3.578/DF, não tratou acerca da possibilidade de 
bancos privados administrarem depósitos judiciais. Entende que o Supremo apenas concluiu pela impossibilidade de as instituições financeiras vencedoras de processos de privatização permanecerem por tempo indeterminado como depositárias desses valores, em detrimento da autonomia do Poder Judiciário. Assevera que "a decisão do STF reconhece a validade e a conveniência da conduta do TJRJ, como forma inteligente de obtenção de receita".

A Corte Paulista firma seus argumentos em Parecer formulado pelo então Professor Luís Roberto Barroso (atual Ministro do STF), que na análise do art. 666 do CPC/73, atual artigo 840, I, do Novo CPC, assentou a tese de que "o claro propósito do legislador foi acabar com a obrigatoriedade do depósito em bancos estatais". Considera, ainda, que "ao empregar o advérbio preferencialmente, o legislador atribuiu certa margem de discricionariedade ao agente público, facultando-lhe o exercício de escolhas motivadas, se entender o caso". O TJSP entende que a única concepção possível do termo "preferencialmente" corresponde à preferência em igualdade de condições com as propostas apresentadas pelas demais instituições financeiras oficiais (públicas ou privadas) que disputam o certame licitatório.

Por fim, informa que o Contrato no $147 / 14$, celebrado entre o TJSP e o Banco do Brasil S/A e referente à administração dos depósitos judiciais, está prestes a encerrar. Neste particular, esclarece que o Banco do Brasil apresentou proposta de renovação com indicativo de taxas muito inferiores àquelas praticadas no mercado e até mesmo em relação à taxa prevista no atual contrato. Informa que a proposta apresentada em 2019, mantidos os mesmos parâmetros da taxa Selic em 6,5\% ao ano, é menos da metade da proposta ajustada em 2018, podendo acarretar prejuízos bilionários aos cofres públicos. A par disso, reputa inadmissível que tal situação se perpetue, "sobrepondo o interesse econômico particular de uma instituição financeira, pautado pela potencialização de seu lucro, ao interesse público na prestação jurisdicional efetiva e de qualidade".

Entende, assim, que os fundamentos outrora adotados nos precedentes deste Conselho não se coadunam com a ordem constitucional vigente.

Por todo o exposto, pleiteia a concessão de medida liminar que autorize o TJSP a deflagrar disputa licitatória entre bancos públicos e privados para a contratação de serviços de administração de depósitos judiciais. Alternativamente e ainda em sede de liminar, requer a manutenção da remuneração atualmente praticada no Contrato no 147/2014, até julgamento definitivo pelo Plenário deste Conselho. No mérito pugna pela autorização para contratar, 
mediante procedimento licitatório, serviços de administração de depósitos judiciais junto às instituições financeiras, públicas ou privadas, assegurando-se que, em caso de empate entre as propostas, seja garantida a "preferência legal" concedida às instituições públicas.

É o relatório.

Passo ao voto.

\section{Voto}

\section{Conhecimento}

Relevante registrar, inicialmente, que o tema em análise, sua contextualização e efetiva aplicabilidade pelo Poder Judiciário, demanda exclusiva avaliação de mérito do instituto jurídico relacionado ao objeto da causa e dos dispositivos legais correlatos, não configurando imprescindível o aprofundamento da demanda em instrução probatória. A rigor, o que se busca no presente feito é a adequada instrumentalização dos depósitos judiciais destinados à administração dos recursos financeiros penhorados para garantia e efetividade dos direitos assegurados aos jurisdicionados.

Envolve, pois, análise interpretativa de adequação da norma ao procedimento buscado pela administração do Tribunal.

A par disso, recebo do presente feito como Consulta, nos termos do art. 89 do RICNJ, e determino que a Secretaria Processual deste Conselho proceda a consequente alteração da classe processual.

Ciente das circunstâncias e particularidades da demanda, passo para a avaliação de mérito.

O procedimento de consulta se encontra regulada no artigo 89 do Regimento Interno deste Conselho, asseverando que "o plenário decidirá sobre consultas, em tese, de interesse e repercussão gerais quanto à dúvida suscitada na aplicação de dispositivos legais e regulamentares concernentes à matéria de sua competência".

A norma supra direciona a aplicação do procedimento para os casos de repercussão geral, não sendo apropriado para solucionar dúvidas individuais sobre casos concretos (CNJ - CONS 0003164-41.2016.2.00.0000). Todavia, há situações, como a que se posta no presente feito, em que os efeitos da interpretação do dispositivo legal ou regulamentar transbordam a individualidade e atingem um número indeterminado de pessoas. 
Vale dizer que, embora o questionamento, tal como formulado, revele pretensão de sanar dúvida quanto à contratação de instituição bancária responsável pela administração dos depósitos judiciais no âmbito do Tribunal consulente, denota-se que a solução do caso perpassa pela conformação e apresentação de esclarecimentos relevantes para todos os tribunais e jurisdicionados do país, os quais devem receber atenção legítima e eficiente na administração dos seus bens pelo Poder Judiciário, não podendo este Conselho se afastar da análise de tão importante e atual demanda (Precedente: CNJ Consulta no 0011175-88.2018.2.00.0000).

Assim, por vislumbrar presentes os requisitos regimentais para o processamento da demanda, conheço da presente consulta.

\section{Fundamentação}

No caso em análise, o Tribunal apresenta questionamento que toca à administração dos recursos financeiros apreendidos pelo Poder Judiciário e alocados em instituição bancária responsável pela guarda e atualização dos respectivos valores. Mais especificamente, indaga sobre a possibilidade de deflagrar disputa licitatória para contratação de serviços de administração dos depósitos judiciais com participação de bancos públicos e privados.

Esclarece, porém, que em razão do encerramento próximo do Contrato no 147/2014, celebrado entre o TJSP e o Banco do Brasil S/A, a ocorrer em 15.08.2019; e tendo o Banco do Brasil apresentado proposta de renovação com indicativo de taxas muito inferiores àquelas praticadas no mercado e até mesmo em relação àquelas ajustadas no anterior contrato, o TJ considera prejudicial para os jurisdicionados e para o Poder Público a perpetuação da situação proposta, "sobrepondo o interesse econômico particular de uma instituição financeira, pautado pela potencialização de seu lucro, ao interesse público na prestação jurisdicional efetiva e de qualidade".

Não se refuta que o tema em análise já foi objeto de apreciação por este Conselho nos autos do $\underline{\text { PCA n }} \underline{0000211-85.2008 .2 .00 .0000}$, de relatoria do então Conselheiro ALTINO PEDROZO DOS SANTOS. Naquela oportunidade, a maioria do Plenário entendeu que os depósitos judiciais devem ser realizados, preferencialmente e como regra, em estabelecimento de crédito oficial (público), admitindo-se que o sejam em estabelecimento privado apenas na hipótese de inexistência daquele na localidade. 
Vejamos a ementa do referido julgado:

DEPÓSITOS JUDICIAIS. CONTAS. ADMINISTRAÇÃO. OBRIGATORIEDADE DE LICITAÇÃO. PREFERÊNCIA LEGALDAS INSTITUIÇÕES BANCÁRIAS OFICIAIS.

I - A administração de contas de depósitos judiciais constitui prestação de serviços por instituição financeira e a sua concessão pelo Poder Judiciário há de ser precedida de licitação, diante do disposto no artigo 37, inciso XXI, da Constituição Federal, e na Lei no

II - Nos termos do artigo 666, inciso I, do Código de Processo Civil e leis correlatas, os depósitos judiciais devem, preferencialmente, como regra, ser realizados em estabelecimento de crédito oficial, admitindo-se que o sejam em estabelecimento de crédito privado apenas na hipótese de inexistência daquele na localidade da sede do órgão do Poder Judiciário.

III - Procedimento de Controle Administrativo de que se conhece e que se julga procedente.

(CNJ - PCA - Procedimento de Controle Administrativo - 000021185.2008.2.00.0000 - Rel. ALTINO PEDROZO DOS SANTOS 73를 Sessão Ordinária Sessão - j. 04/11/2008).

Ocorre que, naquela ocasião, a avaliação foi realizada à luz do anterior Código de Processo Civil de 1973 (art. 666) e da realidade então vivenciada pelo sistema financeiro do país, de maior proximidade histórica aos rompantes inflacionários da economia e de dependência ao mercado internacional; fatores que sabidamente reprimiam a atuação do sistema bancário brasileiro (GIAMBIAGI, Fábio; BARROS DE CASTRO, Lavínia. Economia brasileira contemporânea. 3. ed. Elsevier, 2016).

Não obstante as ponderações que ensejaram a fundamentação do supramencionado precedente, e mesmo já naquela ocasião, alguns Conselheiros apresentaram interpretação visionária dos dispositivos legais aplicáveis ao caso, ao considerar que ao atribuir ao vocábulo "preferencialmente", constante do art. 666 do CPC de 1973, a mesma acepção de "exclusivamente", far-se-ia tábula rasa da inovação introduzida pela Lei no $11.383 / 06$ ao mesmo dispositivo, o que é inadmissível. Em seu voto divergente, o então Conselheiro, Ministro JOÃO ORESTE DALAZEN, asseverou que o advérbio preferencialmente sugere "que outras instituições financeiras, além das instituições financeiras públicas, tornaram-se aptas a administrar os depósitos judiciais" (Id. no $\left.{ }^{4} 85875\right)$. 
Observada a atual realidade econômica e diante dos dispositivos do Novo Código de Processo Civil em vigor (Lei no 13.105/2015), com destaque para a própria evolução histórico-sistemática da norma de regência, entendo prudente a reavaliação do caso, notadamente à luz dos princípios constitucionais aplicáveis.

Como cediço, o Depósito Judicial consiste na guarda provisória do patrimônio do devedor pelo Poder Judiciário, até sua efetiva transferência para a parte cujo direito vier a ser reconhecido judicialmente (credor). Pode ser utilizado, em tese, em qualquer processo no qual se debate uma obrigação de pagamento, apesar de visualizado com maior frequência nas ações de execução, onde a obrigação não é adimplida no prazo previamente assinalado.

Assim, com o objetivo de assegurar à parte vencedora a efetividade da decisão judicial, podem os juízes determinar que o valor discutido no processo seja depositado em uma conta bancária antes mesmo da decisão final da ação, com garantia de atualização (juros e correção monetária) desde a data do depósito. A medida mencionada, além de permitir o manuseio dos recursos processuais cabíveis, tem o condão de inibir possíveis condutas de deterioração do patrimônio pelo devedor, o que poderia caracterizar sua insolvência civil. Destaque-se que, na maioria das vezes, os devedores depositam o valor executado não para pagamento ao credor, mas apenas e tão somente para garantia do juízo, visando recurso futuro; realidade que provoca, sabidamente, maior delonga na efetivação da prestação jurisdicional.

Para além dos entraves processuais, observa-se que, apesar do depósito se efetivar perante instituição bancária, os valores permanecem sob a responsabilidade do Poder Judiciário, real guardião do bem apreendido/penhorado. Nesta missão e visando empreender os meios necessários para a constante atualização do capital, os Tribunais celebram convênios com as instituições bancárias existentes na sede da unidade judiciária, para ajuste das diretrizes e das garantias necessárias para a credibilidade da operação pactuada, de sorte a assegurar a mantença do poder de crédito do valor depositado.

Por evidente, como o próprio nome sugere, compete precipuamente ao Poder Judiciário a efetiva responsabilidade pelo "Depósito Judicial", pois o mesmo decorre do seu poder/ação de expropriação, com intervenção direta no patrimônio do devedor para solução e efetividade da decisão judicial. Atuam as instituições bancárias, depositárias por assim dizer, como "Auxiliares da Justiça", respondendo pela atualização dos valores recolhidos (Súmula no 179 
do STJ $)^{1}$ e participando do processo apenas e tão somente para implementação da prestação jurisdicional, com atribuições determinadas pelas normas de organização judiciária, conforme expressamente assinalado no artigo 149 do Código de Processo Civil. ${ }^{2}$

\section{CPC}

Art. 149. São auxiliares da Justiça, além de outros cujas atribuições sejam determinadas pelas normas de organização judiciária, o escrivão, o chefe de secretaria, o oficial de justiça, o perito, o depositário, o administrador, o intérprete, o tradutor, o mediador, o conciliador judicial, o partidor, o distribuidor, o contabilista e o regulador de avarias.

Nesse contexto, constituindo o Poder Judiciário como o guardião do patrimônio de terceiro, cabe a ele a obrigação de conservação do capital, devendo, para tanto, perquirir e adotar todos os meios necessários para a manutenção do poder de crédito do valor penhorado, sob pena de responsabilização pelas possíveis perdas monetárias (art. 161 do CPC). ${ }^{3}$ Por evidente, torna-se imprescindível a colheita e a análise das melhores propostas de gestão do capital, não podendo ser simples e livremente alocado em determinada instituição financeira, que por vezes apresenta as propostas mais deficitárias de rentabilidade, em prejuízo à atualização adequada do capital e à esperada eficiência do Poder Judiciário.

$\mathrm{Na}$ análise dos dispositivos da legislação adjetiva civil que importam para o exame da matéria, relevante a interpretação histórico-sistemática das alterações produzidas.

Num primeiro momento, o artigo 666, inciso I, do Código de Processo Civil asseverava originalmente que:

1 STJ - Súmula n. 179 - “O estabelecimento de crédito que recebe dinheiro, em depósito judicial, responde pelo pagamento da correção monetária relativa aos valores recolhidos".

2 CPC - "Art. 149. São auxiliares da Justiça, além de outros cujas atribuições sejam determinadas pelas normas de organização judiciária, o escrivão, o chefe de secretaria, o oficial de justiça, o perito, o depositário, o administrador, o intérprete, o tradutor, o mediador, o conciliador judicial, o partidor, o distribuidor, o contabilista e o regulador de avarias".

3 CPC - "Art. 161. O depositário ou o administrador responde pelos prejuízos que, por dolo ou culpa, causar à parte, perdendo a remuneração que lhe foi arbitrada, mas tem o direito a haver o que legitimamente despendeu no exercício do encargo. Parágrafo único. O depositário infiel responde civilmente pelos prejuízos causados, sem prejuízo de sua responsabilidade penal e da imposição de sanção por ato atentatório à dignidade da justiça". 
Art. 666. Se o credor não concordar em que fique como depositário o devedor, depositar-se-ão:

I - no Banco do Brasil, na Caixa Econômica Federal, ou em um banco, de que o Estado-Membro da União possua mais de metade do capital social integralizado; ou, em falta de tais estabelecimentos de crédito, ou agências suas no lugar, em qualquer estabelecimento de crédito, designado pelo juiz, as quantias em dinheiro, as pedras e os metais preciosos, bem como os papéis de crédito;

II - em poder do depositário judicial, os móveis e os imóveis urbanos;

III - em mãos de depositário particular, os demais bens, na forma prescrita na Subseção V deste Capítulo.

Como se denota, o texto original estava vazado de uma linguagem imperativa, possuindo na expressão "depositar-se-ão" um comando visivelmente impositivo para efetivação da ordem de depósito nas instituições bancárias assinaladas (Banco do Brasil, Caixa Econômica ou banco do qual o Estado possua mais da metade do capital social). Permitia o depósito nas demais instituições (privadas) apenas e tão somente de forma excepcional, quando da impossibilidade de o depósito se efetivar nas instituições públicas.

O referido dispositivo foi alterado em 06 de dezembro de 2006 pela Lei no 11.382 , que assim passou a dispor:

Art. 666. Os bens penhorados serão preferencialmente depositados:

I - no Banco do Brasil, na Caixa Econômica Federal, ou em um banco, de que o Estado-Membro da União possua mais de metade do capital social integralizado; ou, em falta de tais estabelecimentos de crédito, ou agências suas no lugar, em qualquer estabelecimento de crédito, designado pelo juiz, as quantias em dinheiro, as pedras e os metais preciosos, bem como os papéis de crédito;

II - em poder do depositário judicial, os móveis e os imóveis urbanos;

III - em mãos de depositário particular, os demais bens.

$\$ 1^{0}$ Com a expressa anuência do exequente ou nos casos de difícil remoção, os bens poderão ser depositados em poder do executado.

$\$ 2^{\mathbf{0}}$ As joias, pedras e objetos preciosos deverão ser depositados com registro do valor estimado de resgate.

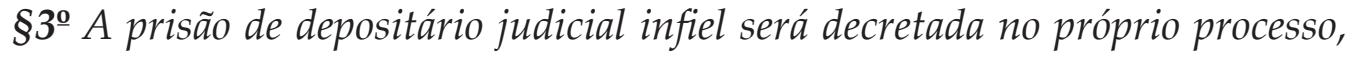
independentemente de ação de depósito. 
Aderindo à interpretação já apresentada quando da discussão do PCA n⿳0 211-85, sob o ponto de vista da divergência, denota-se que a nova redação, a agora em vigor, introduziu o advérbio "preferencialmente" com o claro e inequívoco intento de possibilitar que as propostas de outras instituições financeiras possam ser avaliadas e levadas em consideração pela Administração do Tribunal, quando do regular procedimento licitatório, tendo sempre presente a necessidade de possibilitar melhor rentabilidade e segurança do capital penhorado, de sorte a evitar sua desvalorização e consequente responsabilização do agente depositário mediato.

E de relevo, ainda, que na hipótese de propostas semelhantes entre instituições pública e privada, que seja a decisão em prol do banco público, preferencialmente, na medida em que a preferência estaria amparada pelos demais critérios aqui já destacados - rentabilidade e segurança do capital disputado.

Está claro, no meu sentir, que o Novo Código de Processo Civil, publicado em 17 de março de 2015, reafirmou a mesma orientação, ao manter a expressão "preferencialmente" na redação do atual artigo 840.

Art. 840. Serão preferencialmente depositados:

I - as quantias em dinheiro, os papéis de crédito e as pedras e os metais preciosos, no Banco do Brasil, na Caixa Econômica Federal ou em banco do qual o Estado ou o Distrito Federal possua mais da metade do capital social integralizado, ou, na falta desses estabelecimentos, em qualquer instituição de crédito designada pelo juiz;

II - os móveis, os semoventes, os imóveis urbanos e os direitos aquisitivos sobre imóveis urbanos, em poder do depositário judicial;

III - os imóveis rurais, os direitos aquisitivos sobre imóveis rurais, as máquinas, os utensílios e os instrumentos necessários ou úteis à atividade agrícola, mediante caução idônea, em poder do executado.

$\S 1^{\circ}$ No caso do inciso II do caput, se não houver depositário judicial, os bens ficarão em poder do exequente.

$\$ 2^{\circ}$ Os bens poderão ser depositados em poder do executado nos casos de difícil remoção ou quando anuir o exequente.

$\$ 3^{\circ}$ As joias, as pedras e os objetos preciosos deverão ser depositados com registro do valor estimado de resgate. 
A normatização acima esposada objetivou conferir efetividade à administração da Justiça, em detrimento de condutas abusivas e economicamente prejudiciais.

O termo "preferencialmente", alocado de forma democrática no tratamento da matéria e respeitada a evolução histórico-sistemática da norma, tem o condão de assegurar o reconhecimento da necessária autonomia do Tribunal (e do respectivo juízo) em poder avaliar a proposta mais adequada para a administração dos depósitos judiciais, afastando aquelas economicamente desvantajosas para a rentabilidade das contas. Retira das instituições financeiras públicas a "exclusividade" na administração dos depósitos judiciais, tornando o universo das instituições financeiras privadas uma alternativa para a gestão dos recursos penhorados.

Conforme consignado, ao empregar o advérbio "preferencialmente", o legislador atribuiu margem de discricionariedade ao agente público, facultando-lhe o exercício de escolhas motivadas, devidamentefundamentadas na realidade do caso concreto.

Trata-se, assim, de uma ordem preferencial e não obrigatória.

É certo que a norma adjetiva preconiza a preferência do Banco do Brasil, da Caixa Econômica Federal ou de banco do qual o Estado possua mais da metade do capital integralizado. Não obstante, essa preferência não deve ser vista de forma absoluta e irretratável. Cuida, em verdade, de assegurar predileção das instituições com maior capital público quando da constatação de propostas semelhantes ou equivalentes economicamente.

Essa constatação decorre da mudança de paradigma da Administração Pública, que busca abandonar o modelo burocrático enraizado na história das instituições públicas brasileiras, de reconhecida ineficiência; para aplicação do modelo gerencial no processo de evolução e aprimoramento da administração pública. Esse movimento ocorre em razão de uma cobrança da sociedade pela melhoria dos serviços públicos, contribuindo para a revisão das funções do Estado.

Nesse contexto, percebe-se que o termo "preferencialmente" indica uma nova posição estatal diante das necessidades dos jurisdicionados e da conjuntura vivida pelo Poder Judiciário em pleno século XXI, estando a exigir a ampliação do universo de instituiçõos financeiras aptas a administrar os depósitos judiciais não tributários.

Em robusto Parecer sobre o tema (Id. nº 3672057), o então Jurista e Professor LUÍS ROBERTO BARROSO, atual Ministro do Supremo Tribunal Federal (STF), discorreu com embasado acerto que o propósito da alteração normativa 
(art. 666 para o atual texto do art. 840) foi acabar com a obrigatoriedade do depósito em bancos estatais, sobretudo após a privatização da maioria dos bancos estaduais, adequando o dispositivo aos princípios constitucionais em vigor.

Cite-se:

\section{PARECER - LUÍS ROBERTO BARROSO (trecho)}

\section{$[\ldots]$}

62. A aplicação desses conceitos doutrinários à interpretação do art. 666, I, do CPC produz uma conclusão bastante simples. Como se viu, o argumento infraconstitucional suscitado pelo Banco do Brasil como fundamento de invalidade do convênio firmado entre o TJRJ e o Bradesco (e que impressionou, em um primeiro momento, o CNJ) foi o de que, por força do art. 666, I do CPC, o Tribunal estaria obrigado a selecionar, para recebimento e administração dos depósitos judiciais, banco público sob controle da União. Ou seja: o Banco do Brasil ou a Caixa Econômica Federal. Reduzidíssimo universo, em país com mais de uma dezena de instituições financeiras de primeira linha. Confira-se mais uma vez a redação do preceptivo em questão:

"Art. 666. Os bens penhorados serão preferencialmente depositados: I - no Banco do Brasil, na Caixa Econômica Federal, ou em um banco, de que o Estado-Membro da União possua mais de metade do capital social integralizado; ou, em falta de tais estabelecimentos de crédito, ou agências suas no lugar, em qualquer estabelecimento de crédito, designado pelo juiz, as quantias em dinheiro, as pedras e os metais preciosos, bem como os papéis de crédito".

63. Já se mencionou o contexto em que editada a norma e a inovação que pretendia trazer à ordem jurídica. A redação acima transcrita foi dada pela Lei $n^{\underline{0}}$ 11.386, de 2.12.2006, em substituição ao texto anterior, que impunha de maneira cogente o depósito de bens penhorados em bancos estatais. Confira-se a redação do caput do art. 666 do CPC que vigorava até então:

"Art. 666. Se o credor não concordar em que fique como depositário o devedor depositar-se-ão: [...]"

64. O claro propósito do legislador foi acabar com a obrigatoriedade do depósito em bancos estatais que, sobretudo após a privatização da maioria dos bancos estaduais, perdeu sua razão de ser. Na verdade, a nova redação promoveu uma adaptação do dispositivo à Constituição, sob pena de poder ser considerado inconstitucional por violação ao princípio federativo, ao princípio da 
livre-iniciativa e às regras que disciplinam a atuação econômica direta do Estado, já examinadas acima.

65. Por evidente, preferencial é diferente de obrigatório. Ao empregar o advérbio preferencialmente, o legislador atribuiu certa margem de discricionariedade ao agente público, facultando-lhe o exercício de escolhas motivadas, se entender ser o caso. A interpretação conforme a Constituição do art. 666, I do CPC oferece as seguintes possibilidades de sentido:

a) o administrador público estadual pode optar por efetuar os depósitos judiciais no Banco do Brasil ou na Caixa Econômica Federal, aceitando a preferência eleita pelo legislador federal e deixando de realizar procedimento seletivo;

b) o administrador público pode não aceitar o critério preferencial proposto pelo legislador federal, optando por realizar procedimento seletivo visando à escolha da melhor proposta para a Administração, observados os princípios constitucionais e legais. A interpretação de que o administrador estadual é obrigado a escolher o banco estatal e proibido de fazer o procedimento seletivo é inválida e deve ser declarada inconstitucional, sem redução de texto, isto é, sem que o art. 666, I tenha de ser riscado do CPC.

66. Em síntese: o art. 666, I do CPC legitimaria eventual opção do Tribunal de Justiça por depositar os bens penhorados no Banco do Brasil ou na Caixa Econômica Federal. Contudo, jamais poderia servir de fundamento para impedir o Tribunal de Justiça de realizar procedimento seletivo para escolha de instituição financeira sólida, pública ou privada, que, disputando em condições de igualdade, oferecesse melhor proposta, de acordo com um julgamento objetivo. Obrigar o Estado-membro e seus órgãos, contra a sua vontade, a firmarem convênio com instituição financeira da União viola, em extensão e profundidade relevantes, o princípio federativo, o princípio da livre-iniciativa e as normas que impõem a igualdade entre o particular e o Estado, quando este se dedique à exploração de atividade econômica.

Em sua proficiente análise sobre a administração dos depósitos judiciais, sua natureza jurídica e destinação específica, o Eminente Ministro Luís Roberto Barroso concluiu que " $a$ interpretação de que o administrador estadual é obrigado a escolher o banco estatal e proibido de fazer o procedimento seletivo é inválida".

De acordo com o seu entendimento, o administrador público pode (i) optar por efetuar os depósitos judiciais no Banco do Brasil ou na Caixa 
Econômica Federal, aceitando a preferência eleita pelo legislador federal e deixando de realizar procedimento licitatório. Não obstante, igualmente legítima a posição do administrador que, (ii) não aceitando o critério preferencial proposto pelo legislador, opte por realizar procedimento seletivo (licitação) visando à escolha da proposta mais adequada para a administração dos recursos dos particulares, observados os regramentos legais e princípios constitucionais aplicáveis.

O entendimento firmado no Parecer supramencionado consagra aplicabilidade ao princípio constitucional da autonomia dos tribunais, constante do art. 96, inciso $\mathrm{I}$, alínea ' $\mathrm{b}$ ', da CF/88, cuja redação registra competir privativamente ao tribunal organizar e administrar seus serviços auxiliares, aqui incluídos, por lógico, aqueles prestados pelos auxiliares da Justiça (bancos). Cite-se:

\section{$\mathrm{CF} / 88$}

Art. 96. Compete privativamente: I - aos tribunais:

[...]

b) organizar suas secretarias e serviços auxiliares es dos juizos que lhes forem vinculados, velando pelo exercício da atividade correicional respectiva.

Essa autonomia se vislumbra com maior firmeza quando da constatação de que a norma em análise, art. 840 do CPC, direciona orientação para efetivação de uma ordem judicial de depósito, ou seja, a ser objeto de interpretação pelo respectivo Magistrado competente para julgamento da causa que envolva depósito judicial. Por evidente, cabe ao Juiz avaliar na origem a melhor adequação da ordem de preferência assinalada no dispositivo mencionado, não sendo esta (ordem) absoluta ou peremptória.

Assim, a avaliação da preferência assinalada no mencionado dispositivo constitui o fundamento de uma decisão judicial, cujo teor não pode ser objeto de reavaliação na seara administrativa.

Nesse sentido, cite-se entendimento doutrinário de André Luiz Monteiro e José Antonio Fichtner, ao tecerem comentários sobre o abordado artigo do Novo Código de Processo Civil:

Os bens penhorados devem ser preferencialmente depositados em poder das pessoas ou dos estabelecimentos previstos neste artigo, MAS NÃO SE TRATA DE UMA LISTA EXCLUSIVA, pois razões ligadas ao caso concreto podem 
justificar a nomeação de outros depositários. Isso significa, em outras palavras, que a nomeação pelo juiz de depositários não previstos neste dispositivo é plenamente possível quando o caso o recomendar. É importante, todavia, neste caso, fundamentar o porquê de não se seguir a regra geral da nomeação do depositário de acordo com este dispositivo legal do CPC/2015.

(Associação dos Advogados de São Paulo e Ordem dos Advogados do Brasil - Seccional do Paraná. Código de Processo Civil Anotado, 2018, pg. 1357-1358.) (grifo não no original)

Entendimento semelhante é defendido pelos Professores Fredie Didier Jr., Leonardo Carneiro da Cunha e outros:

O trecho final do $\S 2^{\circ}$ do art. 840 do CPC, combinado com o art. 190 do CPC, demonstra, claramente, a possibilidade de haver negócio processual de escolha do depositário que pode ser, inclusive, um terceiro. Assim, podem as partes convencionar que valores de aplicação financeira penhorados podem permanecer depositados em determinado fundo de investimento gerido por um banco privado em vez de serem transferidos para uma conta judicial num dos bancos previstos no inciso I do art. 840, CPC.

(Didier Jr., Fredie. Curso de direito processual civil: execução. Fredie Didier Jr., Leonardo Carneiro da Cunha, Paula Sarno Braga, Rafael Alexandria de Oliveira. 7. ed. rev., ampl. e atual. Salvador: Ed. JusPodivm, 2017. p. 853). (grifo não no original)

Na análise dos preceitos constitucionais, a interpretação de que os depósitos judiciais devem ser efetivados prioritariamente nos bancos públicos encarta evidente descompasso ao princípio federativo, constante do artigo $1^{\text {o }}$ da Constituição Federal, ${ }^{4}$ cuja norma preconiza que o "Estado Democrático de Direito" deve ter como fundamento, dentre outros, os valores sociais do trabalho e da livre-iniciativa.

A hermenêutica constitucional não consagra qualquer espécie de "monopólio" em favor dos bancos públicos, sob pena de vulneração aos princípios

4 CF/88 - "Art. 1ํA República Federativa do Brasil, formada pela união indissolúvel dos Estados e Municípios e do Distrito Federal, constitui-se em Estado Democrático de Direito e tem como fundamentos: I - a soberania; II - a cidadania; III - a dignidade da pessoa humana; IV - os valores sociais do trabalho e da livre-iniciativa; $V$ - o pluralismo político. Parágrafo único. Todo o poder emana do povo, que o exerce por meio de representantes eleitos ou diretamente, nos termos desta Constituição". 
federativo, da livre-iniciativa e das normas que vedam o favorecimento de empresas estatais quando exploradoras da atividade econômica. Oportuno assinalar que o art. 177 da Constituição Federal, ${ }^{5}$ ao definir as atividades exercidas sob o monopólio da União, não estabeleceu, dentre elas, a atividade que importa para a administração dos depósitos judiciais.

Nesse contexto, relevante a construção técnica assentada nas lições dos Professores Adilson Abreu Dallari e Diogo de Figueiredo Moreira, respectivamente:

Mas é a superior interpretação teleológica que o confirma, uma vez que não se deve entender que o art. 164, §3ํㅡ, haja instituído algum tipo esconso de monopólio econômico em favor de bancos estatais. Com efeito, tal entendimento seria incompatível com o princípio fundamental da livre-iniciativa (art. $1^{\stackrel{0}{ }}, I \mathrm{~V}$, CF) e o princípio geral econômico da livre concorrência (art. 170, IV, CF). Afinal, não se teria dado, o Governo Federal, ao extenuo e penoso trabalho de privatizar os bancos estaduais, que proliferavam em precária situação, com passivos descobertos gigantescos, se assim não fora. Há de se concluir, portanto não apenas pela inexistência desse esdrúxulo monopólio, como, ao revés, de um comando liberalizador, para que os Estados e Municípios, no gozo da autonomia político-administrativa (art.18,CF), oficializem, como melhor lhes parecer, suas respectivas instituições financeiras (art. 192, I, CF), naturalmente, através de licitação, salvo nas hipóteses em que haja impossibilidade de competição, pois somente assim se assegura que o contrato de depósito dos dinheiros públicos oferecerá as maiores vantagens para os Erários.

(DIOGO DE FIGUEIREDO MOREIRA NETO. Considerações sobre a lei de responsabilidade fiscal. 2001. p. 237-238)

[...] [N]ão se pode interpretar o vocábulo "oficial" como correspondente a "público", pois é claríssima a opção contida na Constituição de 1988 pela

5 CF/88 - "Art. 177. Constituem monopólio da União: I - a pesquisa e a lavra das jazidas de petróleo e gás natural e outros hidrocarbonetos fluidos; II - a refinação do petróleo nacional ou estrangeiro; III - a importação e exportação dos produtos e derivados básicos resultantes das atividades previstas nos incisos anteriores; IV - o transporte marítimo do petróleo bruto de origem nacional ou de derivados básicos de petróleo produzidos no País, bem assim o transporte, por meio de conduto, de petróleo bruto, seus derivados e gás natural de qualquer origem; $V$ - a pesquisa, a lavra, o enriquecimento, o reprocessamento, a industrialização e o comércio de minérios e minerais nucleares e seus derivados, com exceção dos radioisótopos cuja produção, comercialização e utilização poderão ser autorizadas sob regime de permissão, conforme as alíneas b e c do inciso XXIII do caput do art. 21 desta Constituição Federal". 
valorização da iniciativa privada, erigindo-a ao nível de princípio. No momento histórico marcado pela desestatização e pela privatização, não é possível aceitar interpretação do texto constitucional em sentido contrário. Além disso, cabe lembrar o princípio federativo, segundo o qual as entidades componentes da federação brasileira são dotadas de autonomia administrativa e financeira. [...] não há razão alguma para sustentar o monopólio dos bancos públicos, pois eles não são mais seguros ou confiáveis que os bancos privados.

(ADILSON DE ABREU DALLARI. Disponibilidades de caixa e as instituições financeiras oficiais. Boletim de Direito Municipal-SP, 17.7.2001)

Registre-se que os depósitos judiciais não tributários não se equiparam, sob qualquer pretexto ou fundamento, ao conceito de "disponibilidade de caixa" constante do artigo 164, $3^{\circ}$, da Constituição Federal. ${ }^{6}$

O depósito judicial se consubstancia no ato de expropriação no patrimônio das partes do processo, a evidenciar a natureza exclusivamente privada do recurso penhorado. Figura o Poder Judiciário apenas e tão somente como responsável provisório pelos respectivos valores, não podendo se eximir de entregar/devolver a quem de direito, com a devida atualização. Lado outro, a “disponibilidade de caixa" a que se refere o $\S 3^{\circ}$ do art. 164 da CF/88 constitui recurso público que compõe o ativo circulante do Estado, ainda não vinculado às despesas correntes.

Portanto, diante de hipóteses distintas os tratamentos devem ser distintos.

Por fim, não se olvida que o sistema financeiro nacional passou por visível desenvolvimento nos últimos anos, se constituindo de instituições financeiras de solidez reconhecida e atestada pelo mercado, conforme análise técnica e estudos criteriosos realizados pelo próprio Banco Central do Brasil, que em seu Relatório de Estabilidade Financeira do ano de 2018 reconhece que "as instituições bancárias vêm mantendo colchões de liquidez suficientes para suportar cenários de estresse" (www.bcb.gov.br/htms/estabilidade/2018_04/refPub.pdf).

Nessa esteira, relevante assinalar que compete privativamente ao Banco Central do Brasil não apenas a fiscalizaçãó ${ }^{\underline{7}}$ das instituições financeiras em

6 CONSTITUIÇÃO FEDERAL - “Art. 164. [...] $\$ 3^{\circ}$ As disponibilidades de caixa da União serão depositadas no banco central; as dos Estados, do Distrito Federal, dos Municípios e dos órgãos ou entidades do Poder Público e das empresas por ele controladas, em instituições financeiras oficiais, ressalvados os casos previstos em lei".

7 Lei no 4.595/64, “Art. 10. Compete privativamente ao Banco Central da República do Brasil: [...] IX - Exercer a fiscalização das instituições financeiras e aplicar as penalidades previstas". 
operação no mercado brasileiro, públicas ou privadas; como também conceder a devida autorização ${ }^{8}$ para o regular funcionamento destas, a fim de que possam funcionar no País, praticando todas as operações, inclusive as de câmbio, intrínsecas à atividade econômica, conforme disposto na Lei n⿳0 4.595/64, que trata das instituições monetárias, bancárias e creditícias.

Assim, como gestor do sistema e visando a segurança do mercado/consumidor, possui o BCB conhecimento próprio para o controle das instituições financeiras em operação, não competindo a este Conselho invadir esta seara.

Não obstante, qualificando-se como guardião do patrimônio penhorado, tem o Poder Judiciário a missão de adotar mecanismos necessários para a seleção de instituição financeira com suporte logístico e creditício suficiente para a segurança dos depósitos judiciais, observado o volume operacional de cada Estado e as particularidades inerentes.

Nesse sentido, quando do procedimento seletivo, deve a administração do Tribunal estabelecer requisitos de habilitação para a contratação da instituição financeira, a qual deverá apresentar qualificação técnico-financeira minimamente suficiente para a segurança e rentabilidade do montante do capital envolvido, além de outros requisitos legais (ex.: art. 27 e art. 116 da Lei no 8.666/93).

Utilizando como parâmetro as diretrizes adotadas pelo Banco Central do Brasil em seus diversos normativos, os quais se alinham às recomendações internacionais do Comitê de Basileia para Supervisão Bancária (Basel Committee on Banking Supervision), ${ }^{9}$ pode o Tribunal avaliar indicadores de capacidade financeira das instituições interessadas em participar da seleção, com apontamento de limites prudenciais de adequação do capital

8 Lei no 4.595/64, "Art. 10 [...] X - Conceder autorização às instituições financeiras, a fim de que possam: a) funcionar no País; b) instalar ou transferir suas sedes, ou dependências, inclusive no exterior; c) ser transformadas, fundidas, incorporadas ou encampadas; d) praticar operações de câmbio, crédito real e venda habitual de títulos da dívida pública federal, estadual ou municipal, ações, debêntures, letras hipotecárias e outros títulos de crédito ou mobiliários; e) ter prorrogados os prazos concedidos para funcionamento; $f$ ) alterar seus estatutos. $g$ ) alienar ou, por qualquer outra forma, transferir o seu controle acionário".

9 "O Comitê de Basileia para Supervisão Bancária (Basel Committee on Banking Supervision - BCBS) é o fórum internacional para discussão e formulação de recomendações para a regulação prudencial e cooperação para supervisão bancária, composto por 45 autoridades monetárias e supervisoras de 28 jurisdições. O Comitê de Basileia - criado em 1974 no âmbito do Banco de Compensações Internacionais (Bank for International Settlements - BIS) tem por objetivo reforçar a regulação, a supervisão e as melhores práticas bancárias para a promoção da estabilidade financeira. O Banco Central do Brasil (BCB), como membro do Comitê da Basileia desde 2009, busca assegurar que a convergência da regulação financeira brasileira para as recomendações do Comitê de Basileia considere as condições estruturais da economia brasileira." 
(Resolução BACEN no 4.280/2013); ${ }^{10}$ bem ainda, com observação dos índices de qualidade do capital, de capitação, de inadimplência, de rentabilidade, além do próprio Patrimônio de Referência das instituições (Resolução BACEN nº 4.193/2013, ${ }^{11}$ Resolução BACEN no 4.677/2018 e outras), todos a justificar a esperada fiabilidade e estabilidade financeira das instituições interessadas na administração dos depósitos judiciais (www.bcb.gov.br/ estabilidadefinanceira).

A orientação supra está em consonância com as diretrizes do Tribunal de Contas da União, que em seu Manual de orientações básicas das licitações e contratos assevera que "é dever da Administração, ao realizar procedimentos licitatórios, exigir documentos de habilitação compatíveis com o ramo do objeto licitado, especialmente aqueles que comprovem a qualificação técnica e a capacidade econômico-financeira para participar de licitação na Administração Pública". ${ }^{12}$

\section{Conclusão}

Considerando toda a fundamentação acima apresentada, conheço da presente consulta e respondo positivamente para, aderindo à conclusão firmada no Parecer supramencionado, facultar à administração do Tribunal a possibilidade de: (i) efetuar os depósitos judiciais no Banco do Brasil ou na Caixa Econômica Federal, ou, (ii) não aceitando o critério preferencial proposto pelo legislador e observada a realidade do caso concreto, realizar procedimento seletivo (licitação) visando à escolha da proposta mais adequada para a administração dos recursos dos particulares, com aplicação dos regramentos legais e princípios constitucionais aplicáveis.

É como voto.

Brasília/DF, data registrada no sistema.

Arnaldo Hossepian Junior

Conselheiro Relator

10 BACEN. www.bcb.gov.br/pre/normativos/busca/downloadNormativo.asp?arquivo=/Lists/ Nor mativos/Attachments/48850/Res_4280_v2_L.pdf

11 BACEN. www.bcb.gov.br/pre/normativos/busca/downloadNormativo.asp?arquivo=/Lists/ Nor mativos/Attachments/49006/Res_4193_v5_L.pdf

12 TCU. Manual de orientações básicas das licitações e contratos do Tribunal de Contas da União. 3. ed. Brasília: TCU, 2006. p. 116. 